\title{
1. Introduction: from the managerial capitalism of the society of organizations to the investor capitalism of the ownership society
}

\section{ON REGIMES OF CAPITALISM}

By financialization we mean basically the increased reliance on the finance market and finance capital to secure economic growth in the contemporary economy (Van der Zwan, 2014; Palley, 2013; Krippner, 2005). This shift in competitive capitalism from manufacturing and distribution of physical commodities as being the principal economic activity, to an economy essentially structured on the basis of abstract principles and the accumulation of wealth on the basis of non-tangible assets represents a wide-ranging shift change now being subject to detailed scholarly attention. Rather than starting with an analysis of finance industry statistics, clearly demonstrating the substantial growth of economic value generated in financial services (for example, Crotty, 2008), we can turn an eye to institutional changes. If the post-World War II era until the decline of the Bretton Woods system in the early 1970s (the Nixon Administration dropped out of the system in 1971) has been characterized as what Peter Drucker (1946) once spoke of as the "society of organizations" and Alfred Chandler $(1984,1977)$ refers to as "managerial capitalism," the era after 1979 when Margret Thatcher was elected Prime Minister in the UK and embarked on a radical political change program, is perhaps better described as what Gerald Davis (2010) speaks of as "the ownership society" (a term widely used by the George W. Bush Administration, 2001-2009; Harrington, 2008) and what Michael Useem (1996) calls "investor capitalism." Since the early 1970s, competitive capitalism has undergone a seismic shift in how economic value is accumulated and how it is distributed and shared (Tabb, 2012). For instance, in the US in 1950 the ten largest employers hired 5 percent of the American workforce, but in 2010 that figure was 2.8 percent (Davis, 2010: 333), indicating the decline in large and stable employing firms. In 1950, eight of the top ten employers were manufacturing firms, while in 2009 
they were all in services and retailing, with seven of the largest employers belonging to the latter category. "By March 2009, more Americans were unemployed than were employed in manufacturing, and all signs pointed to further displacement in the goods-producing sector," Davis (2009: 27, original emphasis) observes. Moreover, one single retailer, Walmart, employed about as many Americans (1.4 million) as the 20 largest US manufacturers combined by 2009 (Davis, 2009: 30). In comparison to the American manufacturing industry, which relies on stable and predictable agreements between unions and employers, jobs in retailing are insecure and lower paid, a condition that has increased the economic inequality in the US. As Davis (2009: 27) states "Large corporations have lost their place as the central pillars of American social structure."

Over the last four decades, the American economy has lost many manufacturing jobs, an effect of the political ignorance derived from the economic advice being given that the offshoring of manufacturing jobs to low-cost countries was part of a "natural" change towards more professional and knowledge-intensive work, and an unwillingness to invest in long-term production facilities when there were possibilities for earning higher rents when investing this capital in the burgeoning finance markets. In many ways, the interwar period was the era of large corporations and industries such as the automotive industry and industry leaders such as Alfred P. Sloan, the legendary Chief Executive Officer (CEO) of General Motors, were the masters of the society of organizations (Mizruchi, 2013). During the last four decades, following the economic decline of the 1970s and the radical shift in policy during the Thatcher and Reagan era of the 1980 s, there has been a strong orientation towards the finance industry and the finance market to generate economic value and to coordinate economic activities (Stein, 2011; Stearns and Allan, 1996). Finance market actors today serve the role similar to Sloan and the corporate elites of his generation, to monitor and assess how capital is circulating and accumulating in organizations and networks of organizations. "Nearly three-quarters of the average Fortune 1000 corporation's shares were owned by institutional investors in 2005, with mutual funds making up the most concentrated block," Davis (2009: 33) reports, indicating how large fund and finance companies serve to monitor companies and to align the interests of CEOs and directors with those of finance market actors. As a consequence, the circulation of stocks is substantially higher, indicating that long-term ownership obligations and responsibilities are displaced by an investor culture based on short-term rent seeking: "[w] hereas in 1960, on average, only 12 percent of a New York Stock Exchange-listed company's share would turn over in a year, by 1990 turnover was 46 percent, in 2000, 88 percent, and before the crash of 2008, well over 100 percent" (Tabb, 2012: 53). 
In this new ownership society and regime of investor capitalism, companies are being enacted not so much as a bundle of production facilities but as a portfolio of financial resources and legal contracts. Also human beings working in these corporations and competing over work in the era of financialization have started to re-enact themselves in new terms and have started to think of themselves as enterprising subjects consonant with the expectations laid upon them: "[t]he increasing centrality of finance to everyday life also changed people's understanding of their place in society. Traditional corporate employers provided more than a job - they provided a worldview," Davis (2009: 38) says. In ownership society, the overarching worldview being presented to social actors is to think of oneself as an enterprising individual that competes on the basis of the ability to generate economic value and rents for the employing organization (for example, Neff, 2013; Lane, 2010). The financialization of the economy is therefore essentially an intellectual and ideological shift wherein the accumulation of capital and economic rents are the drivers of the economy.

This book examines the financialization of the firm from a management studies and social theory perspective. The volume does not rely on one single unified theoretical framework but makes use of a variety of literatures including organization theory, economic sociology, political science, finance theory, and economics. The book does not aim to present an equally unified and integrated theory of the financialization of the firm, but to examine the various implications of the financialization of the capitalist economy on the firm level and on the level of the co-workers in organizations. While financialization is a quite recent term in the economic sociology literature (Van der Zwan, 2014), arguably introduced by the edited volume of Epstein (2005), it still captures the longue durée of the contemporary economic system and in policy, rooted in the 1970s' bear market and the economic turmoil derived from the first and second oil crises of the 1970s. As Krippner $(2011,2005)$ has argued persuasively, the outcome from all the policies from the Carter Administration onwards has not always been anticipated, or desired, but instead there has been a significant degree of what Robert Merton (1933) speaks of as "unintended consequences of purposeful action" in this story. In addition, there is an element of opportunism in the equation when the hegemonic Keynesian regulatory economic model started to run out of steam and new groups of economists and economic advisers and policy-makers advanced their positions (Mirowski, 2013; Madrick, 2011; Peck, 2010). In Peter Gay's (1986) excellent monograph on the Weimar culture, the "outsiders" of the German society quickly became "insiders" during the short period of the Republic between World War I and the Nazi takeover. Something quite similar occurred in the US during the 1970s and 1980s, when so-called 
"freshwater" economists at the University of Chicago were increasingly becoming influential in setting the political agenda and in shaping the public mindset regarding the role of the government and the importance of free markets (Jones, 2012). Figures such as Milton Friedman, previously being respected but widely regarded as representing overtly anti-statist and libertarian political views, could now entrench advisory roles in the White House (Burgin, 2012). These changes did not happen overnight but were rather the outcome of a long-term mobilization of conservative and libertarian intellectuals and financiers that were ready to sponsor and fund a new economic theory and policy (Styhre, 2014; Medvetz, 2012; Himmelstein, 1992). This institutional shift is a fascinating story in its own right, and the most conspicuous consequence of this new economic doctrine and policy is the quick expansion of finance markets, that is, the financialization of the economy.

\section{CAPITALISM AS AN ECONOMIC SYSTEM AND REGIMES OF CAPITAL ACCUMULATION}

The concept of financialization is deeply entangled with the abstract category of capital, and more specifically finance capital. In the Western tradition, shaped by Hellenistic philosophy and the Christian and more specifically the Catholic credo, capital qua abstract economic category has historically been treated with great skepticism (Wood, 2002; De Roover, 1974). An inquiry in the financialized economy and the financialization of the firm needs to start with an historical overview of how finance has gradually moved from being a relatively marginal but yet decisive mechanism in economic systems, to become its master and the measure of all things under the sun. Today, finance scholars and pundits at times portray the finance industry as the "motor" of capitalism, or even, when favoring a more neurological metaphor, the "brain" of capitalism. Such metaphors may be regarded as useful and legitimate to varying degrees, and may be more or less justified on the basis of empirical data, but they are nevertheless indicative of a major institutional shift in the economy that has occurred during the last three decades. In the following, an historical view of the relationship between finance capital and capitalism will be provided.

In Max Weber's (1999: 48) account, the capitalist economic system is constituted by a number of key components including "[the] appropriation of the physical means of production by the entrepreneur, freedom of the market, rational technology, rational law, free labor, and finally the commercialization of economic life." In Day's (1987: 142) view, "the birth of capitalism coincides with the emergence of an organized market for 
short-term credit based on foreign exchange." That is, capitalism is by definition grounded in the organization of a structured market for credit and exchanges of different currencies. Day (1987: 143) dates this event to the second half of the thirteenth century, when there was, he continues, a "remarkable growth" of innovations in the field of "financial and business techniques." Needless to say, modern day capitalism with its emphasis on finance capital originated in a hostile environment dominated by the Catholic Church (Tawney, [1926] 1998; Keen, 1968). For the Church fathers, trade, as opposed to work for one's subsistence, was not in itself treated as being "wicked" but since there was always risks involved in trade, such occupations "nevertheless endangered the salvation of the soul" (De Roover, 1974: 336). In addition, usury and money-lending - of vital importance for economic growth as capital investment propels entrepreneurial activities - was condemned as "sin"; to lend money against interest is to capitalize on time, and time belongs to God. Hence, usury is sinful (De Roover, 1974: 336; see also Le Goff, [1986] 1988):

The assumption on which all this body of doctrine rested was simple. It was that the danger of economic interests increased in direct proportion to the prominence of the pecuniary motives associated with them. Labor - the common lot of mankind - is necessary and honorable; trade is necessary, but perilous to the soul; finance, if not immoral, it is at best sordid and at worst disreputable. (Tawney, [1926] 1998: 33)

This theological hostility towards capital circulation and accumulation had its root in Hellenic philosophy. Aristotle, undoubtedly the dominant intellectual figure in the medieval period, argued in his Politics that money is "sterile," and made a careful distinction between oikonomia, "the art of household management," and chrematistike, "the art of money-making" (Swedberg, 1998: 30), wherein the latter was less honorable. Scholastic thinkers addressing economic issues including San Bernardino of Siena consequently condemned usury (De Roover, 1974: 344), and well into the reformation period, protestant theologists such as Martin Luther published texts such as Sermon on Usury (1520) and On Trade and Usury (1524) that condemned usury and profit-making more generally (Tawney, [1926] 1998).

Hard work and poverty had been Christian virtues from its inception. "Blessed are the meek," reads Matthew 5:5, widely understood as an instruction to patiently await future rewards for the toil and hard work in this world, but this conservatism and tolerance or even veneration of poverty and suffering effectively inhibited the development of economic growth and an enterprising culture. A medieval cynic, Benvenuto da Imola (cited in Tawney, [1926] 1998: 8), pointed at the limited choices of the 
medieval laborer or "entrepreneurs" - to use an anachronistic term - in the era of theological prohibition against usury: "[h]e who takes it [interests on loans] goes to hell, and he who does not goes to the workhouse." However, the period from the twelfth to the fifteenth century was marked by "dramatic developments in economic thought and practice within the framework of a changing society" (Wood, 2002: 206), including the emergence of a new merchant class in the prosperous Italian city-states. According to Wood (2002: 207), these social and doctrinal changes saw that "money became the lifeblood of the state." Wood (2002: 207) goes on to say, "[e]specially in early Renaissance Italy, the theoretical position of wealth and poverty was gradually reversed: wealth was exalted and poverty decried." One of the most important contributions of medieval economic thought was therefore the emergence of the concept of interest and its "[d]ivorce from usurious, and therefore sinful, profit" (Wood, 2002: 207). Theology and economic issues and finance in particular were gradually disconnected.

The Italian merchants located in the glorious city-states on the Italian peninsula were the principal innovators in the field of finance (Braudel, 1992). Levitt (2013a: 141) dates the birth of capitalism to a later period than Day (1987), but nevertheless emphasizes the mercantile roots of the capitalist system. In Levitt's view, the emerging maritime states of the Atlantic rim including Great Britain, Portugal, and the Netherlands, and the merchant classes operating in alliance with the national sovereign for "commerce and conquest, trade and art, wealth and territory," were the drivers of capitalism. The essence of capitalism is therefore not, Levitt (2013a) suggests, its superiority of production but instead it is "the superiority in commerce and conquest" that is its primus motor. Of particular importance for the mercantilist phase of capitalism was the legal form of the joint-stock chartered company (Levitt, 2013a: 141), a specific form of economic enterprise based on limited liabilities and ultimately backed by the national sovereign as a tool for geopolitical expansion and the accumulation of wealth of the Western economic centers.

Regardless of the precise dating of capitalism, the role of finance capital is of central importance. Arrighi's (2010) seminal study of the expansion of capital from the Italian mercantile city-states of Venice, Genoa, Florence, and Pisa provides some insight into the role of capital in the expansion of differentiated economic systems, from the Italian peninsula to the trading posts north of the Alps (for example, Bruges). In Arrighi's (2010) narrative, the two principal contestants for being the birthplace of Western capitalism were Venice and Genoa, demonstrating two entirely different trajectories in how they were competing over the Euro-Asian trade routes. Unlike many other towns and cities on the Italian peninsula, Venice was 
not a Roman settlement, but was formed around the turn of the second millennium. In the coming centuries, Venice became a grandiose citystate, a city of many wonders, commercial as well as cultural, developing a sophisticated political system that lasted into the period when Venice was integrated into the new Italian nation state during the Risorgimento of the mid-nineteenth century. Venice organized its economic activity into guilds and developed functional finance systems by the second half of twelfth century, so-called colleganza. By the twelfth century, the Venetians had managed to accommodate the Church's ban on usury, and the supply of capital enabled further economic expansion (Lane, 1973: 144). In addition, the Venetians enacted double-entry standards (albeit the origin of this standard is disputed, with some scholars believing the practice was first developed in Genoa and Tuscany; Lane, 1973: 104), and developed a system of education in so-called scuola d'abbaco (Carruthers and Espeland, 1991: 49), a form of trade schools where the maestro d'abacco, "masters of the abacus," trained the sons of merchants in subjects such as Latin, multiplication, division, fractions, and double-entry bookkeeping (Lane, 1973: 141). In 1474, Venice enacted its first rules on intellectual property rights (IPRs), the archaic form of what constitutes modern patenting law (Wilkinson, 2006: 192). In the sixteenth century, Venice was the European center for book publishing, a position taken over by Amsterdam in the seventeenth century and London in eighteenth century (Briggs and Burke, 2009: 46). In short, Venice championed the development of an advanced economic system, eventually reproduced elsewhere.

Unfortunately, these superior abilities to build an advanced city-state and a differentiated economy made Venetian capitalism "parochial and inward-looking" (Arrighi, 2010: 151), that was also combined with a lack of innovation. The Genoese merchants, in contrast, were operating in a much less stable political system with periods of disruption, civil war, and armed conflicts with for example, nearby Pisa, which made Genoese capitalism "subject to strong centrifugal and innovative thrust," according to Arrighi (2010: 151). When the Genoese military-commercial empire in the Mediterranean and Black Sea regions dissolved, this strive to create new means for expanding the commercial activities beyond the city-state intensified. This leaves Arrighi (2010) with two highly complementary models for capital accumulation and economic growth:

Just as Venice's inherent strength in state- and war-making was its weakness, so Genoa's weakness was its strength. In an attempt to beat Venetian competition, or because they had been beaten by it, the Genoese merchants forced their way into every corner of the European World-economy and opened up new trade routes within and beyond its geographical boundaries. By the beginning of the fifteenth century, they had settlements in the Crimea, Chios, North Africa, 
Seville, Lisbon, and Bruges ... As a result, the Genoese capitalist class came to control a cosmopolitan commercial and financial network of unprecedented and unparalleled scale and scope. (Arrighi, 2010: 152)

As opposed to Venice, located at the boundary between the Orient and the Occident, Genoa had a less strategic position. Still, the Genoans benefitted from being at one of the crossroads of the Mediterranean trade routes. Liguria was a small region, and in comparison to Tuscany or the Seine valley, it was not rich, and the city of Genoa was mocked for its provincialism. For instance, in Jacob Burckhardt's ([1860] 1954) magisterial work on the Italian renaissance culture, an "intellectual bestseller" (albeit avant la lattre) in the second half of the nineteenth century, Genoa is given a most peripheral role in the modernization of politics, art, and literature:

Genoa scarcely comes within range of our task, as before the time of Andrea Doria it took almost no part in the Renaissance. Indeed, the inhabitants of the Riviera was proverbial among Italians for his contempt of all higher culture . . . [A]ll who took part in public affairs were at the same time almost exceptionally active men of business. (Burckhardt, [1860] 1954: 64)

An intellectual's contempt for the merchant and businessman cannot overshadow the fact that the Genoans, a seafaring people, were familiar with "the many cultures that circled the sea" (Epstein, 1996: 162), and that Genoese culture was mercantile: "[i]ts richest citizens were merchants, and the business of the city was trade" (Epstein, 1996: 161).

The commerce bred in the city fostered the profession of notary and several hundred skilled, secular masters of Latin and the law that constituted an educated class that served both the commune and the church and thus advanced Genoa as a center for finance capital (Epstein, 1996: 161). The first deposit banks had been developed in Tuscany in cities such as Florence, Siena, and Lucca, and thereafter they spread to Genoa and Venice (Kindleberger, 2007: 42). Still, Genoa was the site where the first chartered bank, Casa di San Giogio, was established in 1407 (Kindleberger, 2007: 47). The bank had a sophisticated organization and governance structure, and Niccolò Machiavelli described the bank as "a state within the state" (Calomiris and Haber, 2014: 67). The bank's financial competence, political relations, and international connections made it a trusted business partner for not only merchants but also many European monarchs. During the Thirty Years' War (1618-1648), for instance, Philip II of Spain relied on Genoese bankers "to pay his troops and naval forces" (Calomiris and Haber, 2014: 67).

The Genoese commercial and financial class, suffered from the weak and conflict-torn Genoese state, always at risk of disintegrating. For 
this reason, Genoans were more effective in developing trade routes and commercial centers beyond its immediate geopolitical territory than their Venetian competitors. A poem by Genoa's foremost poet, known under the name "The Anonymous," testifies to this deterritorialized expansion of Genoese finance capital.

\author{
E tanti sun li Zenoexi \\ E per lo mondo si distexi \\ Che und'eli van o stan \\ Un'altra Zenoa gè fan
}

Which translates roughly as:

And so many are the Genoese

And so spread out through the world,

That wherever one goes or stays

There, he makes another Genoa

The political volatility of the Genoese city-state made Genoa the first modern capital lending center. Bruges in Flanders was the first major site for the Genoese expansion, and by the second half of the fifteenth century, Antwerp gained a more prominent role (Kindleberger, 2007: 37). With Genoese finance market actors leading the way, Italian bankers developed branches in Avignon, Barcelona, Bruges, and later in Lyon, Besançon, Antwerp, Amsterdam, London, and Hamburg during the medieval period (Kindleberger, 2007: 43). Not until the period after 1640 did the finance market initiative move north of the Alps, to the Netherlands and Amsterdam (dominating the 1640-1780 period), and thereafter to Great Britain and London (1780-approx. 1920) (North, 1991; North and Weingast, 1989). Arrighi (2010) summarizes his argument, pointing at the differences between Venice and Genoa:

[T]he Venetian and the Genoese regimes of accumulation developed along divergent trajectories, which in the fifteenth century crystallized into two opposite elementary forms of capitalist organization. Venice came to constitute the prototype of all future forms of "state (monopoly) capitalism," whereas Genoa came to constitute the prototype for all future forms of "cosmopolitan (finance) capitalism." (Arrighi, 2010: 153)

Venice is still today a venerated city of spectacular (but unfortunately decaying and ultimately sinking) beauty, visited by millions of tourists annually. Genoa, having fewer grand sites, remains an easily forgotten but still intriguing city in the northern Mediterranean region, hosting a major port. Today, the city is perhaps best known for its gastronomical innovation pesto and for indirectly influencing everyday language (albeit 
arguably unbeknown to many) as the French name of the city, Gênes, being the root of the word jeans, a term derived from the fabric produced in the Ligurian metropole. Still, we all owe to the Genoans the innovation of the international finance system being today the lifeblood of the capitalist regime of accumulation, especially in the period of financialization. As we will see in the following sections, the Genoese innovation of finance capital being disconnected from a particular national state and its sovereign or government, originally serving as the "lender of last resort," has been the leitmotif of the financialization of competitive capitalism during the recent period. As we have moved from "managerial capitalism" to "investor capitalism," finance capital has gradually become detached from actual tangible assets and has taken on a virtual existence on its own as being what regulates virtually a wider set of social and economic relations.

\title{
MANAGERIALISM AND FINANCIALIZATION: REGIMES OF VALUE CREATION AND VALUE EXTRACTION
}

In early 2002, in the period of the Enron scandal (detailed below), the following joke was circulating on Wall Street:

\begin{abstract}
Enron Venture Capitalism: you have two cows. You sell three of them to your publicly listed company, using letters of credit opened by your brother-in-law at the bank, then execute a debt/equity swap with an associated general offer so that you get all four cows back, with a tax exemption for five cows. The milk rights of the six cows are transferred via an intermediary to a Cayman Island company owned by the majority shareholder who sells the right to all seven cows back to your listed company. The annual report says the company owns eight cows, with an option on one more. (Enron joke, cited in Froud et al., 2004: 886: original emphasis omitted)
\end{abstract}

Anthropologists and other scholars studying jokes and humor (for example, Billig, 2005; Sanders, 2004) tend to regard jokes as a mechanism that enables one to express what is otherwise complicated to give voice to, what evades representation (for a selection of studies of joking and humor in organizations, see Korczynski, 2011; Westwood and Rhodes, 2007; Terrion and Ashforth, 2002; Grugulis, 2002; Hardy and Philips, 1999). "[J]okes are expressive of the social situation in which they occur," Douglas (1999: 152) proposes. In addition, for Douglas (1999: 155), the joke contrasts again the rite; the rite "imposes order and harmony," while the joke "disorganizes" - "Essentially, a joke is anti-rite" (Douglas, 1999: 152). For scholars examining jokes and humor, a joke is "never just a joke," 
but provides a gateway into the collective's cognition, norm systems, and morality. The "Enron Venture Capitalism" joke is thus indicative of the new regime of value extraction practices that were gradually established in not only the American energy company Enron but in the finance industry at large in the era of financialization.

Tabb (2012) uses the term social structure of accumulation (SSA) to denote the integrated institutional structures that dominate during different phases of growth and capital accumulation. An SSA, Tabb (2012: 25) writes, is the creation of "relatively lasting accommodations between capital and labor, the United States [Tabb's nation of analysis] and rest of the world, capital and state, capitalists and other capitalists, and citizens and their governments." Tabb (2012: 26) suggests that an SSA "typically lasts about three decades," and by the beginning of the second decade of the new millennium we are, Tabb 2012: 26) proposes, at the end of the "free-market global neoliberalization." This SSA has the following characteristics: "a free-market ideology, decline in coverage by the social safety net, more individualistic citizen-state relationships, deregulation, harsh capital-labor relations, and reduced financial regulation of banks" (Tabb, 2012: 27). Prior to the free-market global neoliberalization SSA, the "national Keynesian SSA" dominated after the World War II, but this system based on the regulation of markets, the growth of the economy and the welfare state, and a redistribution of economic resources, started to decline in the period from the late 1960s and with notable events such as the US abandonment of the Bretton Woods post-war financial regime and the oil price increase by the Organization of Petroleum Exporting Countries (OPEC) of the early 1970s (Tabb, 2012: 29). While proponents of finance theory and its political implication, the deregulation of finance markets and the accumulation of capital in the finance industry are prone to make claims that finance is the primus motor of the economy as it more effectively allocates resources to high-growth industries, the data speak against such a rosy view of finance: real global growth was 4.9 percent in 1950-1974, 3.4 percent between 1974-1979, and 2.3 percent in the 1990s, Tabb (2012: 31 ) reports. In addition, as will be detailed in the following chapters, the financialization of the economy is associated with a decline in real wages and the increase of household debt: "[b]etween 1973 and 2007 real wages went down by 4.4 percent, in contrast to the 1947-73 increase of 75 percent" (Tabb, 2012: 39); "[h]ousehold debt was little more than half the gross domestic product in 1981. It was equal to 100 percent of GDP in 2007" (Tabb, 2012: 34). Therefore, rather than thinking of economic growth in the era of financialization as being propelled by the increased understanding of underlying capital accumulation mechanisms in terms of for example, higher human capital investment and more 
accurate theories about finance, or caused by investment in productive capital such as machinery or tools, the economic growth is primarily based on increased debt, per se being both the cause and effect of financialization (Montgomerie, 2009).

Under all conditions, the shift to the new SSA, the SSA of financialization, brought a new idea of how economic value is both created and extracted, and distributed in the economy and in firms. While mainstream neoclassical economic theory speaks of value creation in terms of a realistic epistemology, as what actually exists as a substance or "foundational value" (Andersson et al., 2010), heterodox economists and social scientists enact economic value as what is being created in the very accounting apparatus that is bound up with firms' operations. In this view, value creation is less a matter of being an actual event as it is the outcome from calculative practices and financialized operations that do not rely on common-sense distinctions such as between real and synthetic, actual and virtual, economic values. Say Erturk et al. (2010):

It does not make sense to think of value as being created or destroyed by a firm. More accurately, value is made material within accounting regulations and conventions which refract current market prices onto the balance sheet of firms and results in trading and holding gains and losses. Under these conditions, value is not only mutable but also relational insofar as it reflects the often volatile exchanges and sentiments within markets over time. (Erturk et al., 2010: 547)

As a consequence, the traditional view that economic growth is a matter of value creation and accompanying activities to extract value from economic activities is gradually displaced by the view that value extraction occurs independently of actual value creation. "[L]ittle attention has been paid to the tension between how value is created and how value is extracted in modern-day capitalism," Lazonick and Mazzucato (2013: 1094) argue, and add that in the era of financialization, there is an "increasing separation between those economic actors who take the risks of investing in innovation and those who reap the rewards from innovation" (Lazonick and Mazzucato, 2013: 1094). In the era of managerial capitalism, capital owners invested in firms that produced goods and services that were traded in the market and the value created derived from both the innovations being produced by such firms, and the difference between aggregated development and production costs per unit and the market price generating a yield. This generic economic model is no longer fully applicable as new modes of value extraction short-circuit the balance between value creation and value extraction. In the era of financialization, the firm is no longer primarily conceived of as a bundle of productive resources that can 
generate income when used effectively and being skillfully integrated, but instead the firm becomes a portfolio of financial assets that can be used to generate economic value. In this new regime, the deregulation of the financial markets have been the key to the new ways of extracting additional value out of what was previously seen as for example, a production unit. Such deregulatory activities are in turn justified and made legitimate by the advancement of neoclassical finance theory that enacted markets as superior mechanisms for pricing and allocating resources. This is particularly true for finance markets operating on liquid assets such as currencies, stocks, and derivate instruments. However, as the events of 2008 revealed, many newly developed finance assets such as collateralized debt obligations (CDOs) (Bluhm and Wagner, 2011) and mortgage-backed securities (MBSs) (McConnell and Buser, 2011) were substantially less liquid than assumed in bear markets and in situations where the capitalization of finance institutions (that is, risk-taking) are at an extreme level. Regardless of these theoretical inconsistencies, the era of financialization is determined by the ability of certain groups to advance its positions regarding their share of the economic value extracted from firms: "[f]inancial deregulation and the spread of stock-related pay have enabled investors (especially of private equity) and top corporate executives to secure ownership of assets just before major innovation-related gains are capitalized into them," Lazonick and Mazzucato (2013: 1106) argue. Financialization is thus strongly correlated with the growth of economic inequality, ultimately based on institutional changes: "[a] set of socially devised institutions related to corporate governance, stock markets, and income taxation have permitted this concentration of value extraction in a few hands" (Lazonick and Mazzucato, 2013: 1108).

The exemplary case par excellence of how value creation and value extraction diverges in the era of financialization is the Texas energy company Enron. The literature examining the case of Enron is enormous (see for example, Bratton and Levitin, 2013; Ailon, 2012; Tourish and Vatcha, 2005; Craig and Amernic, 2004; Cullinan, 2004; Watkins, 2003; Seeger and Ulmer, 2003) and it is beyond the scope of this book to once again reiterate how one of the most admired and praised companies of the 1990s "new economy" suddenly appeared to be a fraud, leaving many business school professors, experts, and media pundits in the embarrassing situation of not having been able to anticipate how far the Enron executives and board of directors had stretched their moral standards. Enron's innovation was the "the financialization of energy," Froud et al. (2004: 889) write. The somewhat dull energy market was here coupled with new financial innovations and new accounting procedures enabling value creation and value extraction at a new level in the industry. In the period 
from the mid-1990s to its bankruptcy in 2002, Enron managed to grow at a spectacular pace: "Enron tripled sales revenues in 3 years from US\$9 to US\$31 billion between 1995 and 1998 and then tripled sales revenues again from US\$31 to US\$100 billion from 1998 to 2000" (Froud et al., 2004: 891). The so-called new economy, propelled by the commercialization and development of information media and the Internet, was characterized, Froud et al. (2004: 892) suggest, by an increased separation between technological innovations on the one hand, and turnover growth and rising stock prices on the other. In the period 1995 to the information technology bubble burst in 2000 - after the NASDAC index peaked at 5,060 in March 2000, by midsummer the index stood at 3,600 and finally bottomed at less than 1,200, losing more than three-fourths of its value (Baker, 2013: 52 ) - the firm was increasingly enacted as the site of value creation not in terms of actual accomplishments but in terms of the economic value that could be extracted from the yet-to-come innovations. As a consequence, the by now customary divergence between substantial value and market values, and the growth in intangible assets on the firms' balance sheets was justified on basis of expectations. In the case of Enron, combining energy industry and financial and service industry features, the value extracted very much benefited a small group of executives and directors:

In 2000, US $\$ 430$ million was paid out in annual bonuses, and a further US\$320 million was paid to 65 executives under the Performance Unit Plan ... In all, US\$750 million was paid out in cash bonuses when the company's net income for the year was US\$975 billion and the Senate Sub Committee was suitably critical of the board for allowing management to enrich itself with "lavish" bonuses which were not in the shareholders' interest. (Froud et al., 2004: 897)

When Enron eventually proved to use inadequate market reporting and accounting procedures, not only was Enron declared bankrupt, but also Enron's principal accounting firm, Anderson, did not survive the scandal. The case of Enron was the first major scandal that was followed by a number of smaller but still significant cases (for example, WorldCom) of how value creation and value extraction has been cut loose from underlying actual activities and assets in the firm, and where new advanced forms of financial engineering were used to enrich certain stakeholders (White, 2010; Stiglitz, 2009; Sikka, 2009). By the end of the day, the financialization of the economy and companies such as Enron is indicative of the shift in the institutional and regulatory setting being justified on the basis of finance theory and neoclassical economic theory, and its axiomatic belief in the market as being more efficient in pricing assets than any other mechanism. As will be discussed in the forthcoming chapters, there is quite substantial evidence that the new regime of value creation, based 
on intangibles and synthetic financial assets including derivatives, and value extraction, benefiting a smaller group of capital owners, in many ways have destabilized the economy. After 1980, the number of financial bubbles, collapses, and frauds has grown substantially (Blinder, 2013; Gorton, 2010; Black, 2005), partly because of the time it takes to implement new regulatory frameworks (Abdelal, 2007; Singer, 2007) but also because the very idea of value creation and value extraction has changed. These institutional changes will be detailed in this volume.

\section{OUTLINE OF THE BOOK}

This book is composed of this introduction, two parts including two and three chapters respectively, and one final summary chapter. In the first part of the book, Chapter 2 introduces the concept of financialization and Chapter 3 discusses the short-, mid-, and long-term consequences of the new financialized economic regime. The second part of the book addresses firm-level consequences, including corporate governance practices (Chapter 4), new regimes of management control based on the use of external auditing and rating services (Chapter 5), and the changes in workplace control and economic compensation (Chapter 6). In the final chapter, some theoretical implications are discussed and consequences for managerial practice will also be addressed. 
Alexander Styhre - 9781783478231 Downloaded from PubFactory at 04/26/2023 01:34:20PM via free access 